\title{
Mechanisms of Disease
}

\section{The nephrotic syndrome}

\author{
Edwina A. Brown \\ Department of Medicine, Charing Cross \& Westminster Medical School, Fulham Palace Road, London W6 8RF, \\ $U K$.
}

\section{Introduction}

The definition of nephrotic syndrome is proteinuria accompanied by hypoalbuminaemia and oedema. This, however, is not a direct chain of events. In the presence of normal liver albumin synthesis, nephrotic range of proteinuria $(>3.5 \mathrm{~g} / 24 \mathrm{~h})$ should not cause hypoalbuminaemia, and a low plasma albumin concentration itself does not result in oedema formation except in the presence of sodium retention. The cause of this sodium retention remains unknown, but is probably due to some intrarenal mechanism.

\section{Mechanisms of proteinuria}

By measuring the clearances of charged and neutral dextrans of known molecular weights and comparing them to inulin it is possible to study glomerular capillary permeability. Such studies show that in normal animals both molecular charge and size influence the transglomerular passage of circulating macromolecules. Thus, the filtration of the negatively charged albumin is restricted to a much greater extent than is that of a neutral macromolecule of the same size (Chang et al., 1975). This is due to the existence of fixed negative charges on the glomerular capillary wall as demonstrated by the use of cationic 'stains' such as colloidal iron and ruthenium red (Latta et al., 1975; Kanwar \& Farquhar, 1979).

Studies in rats with nephrotoxic serum nephritis or aminonucleoside-induced nephrosis have shown that, at any given molecular size, negatively charged dextran sulphate fractional clearances are greater than those in normal rats (Bennett et al., 1976; Bohrer et al., 1977). This suggests that albuminuria in these disorders is due to a reduction in the fixed negative charges on the diseased glomerular capillary wall. Further support for this theory comes from the finding of

Correspondence: E.A. Brown, D.M., M.R.C.P.

Accepted: 1 May 1985 reduced binding of cationic stains to anionic sites of the glomerular capillary wall in aminonucleosidetreated rats (Michael et al., 1970).

In man, there is also evidence of depleted glomerular polyanion in almost all glomerular diseases associated with proteinuria (Blau \& Haas, 1973). This loss of glomerular electrostatic barrier function would allow the leak of the negatively charged albumin into the urine. There is also increasing evidence that the different protein selectivity found in different causes of nephrotic syndrome can be explained by the fact that in minimal change glomerulonephritis there remains an intact size-selective barrier, while in other glomerular lesions this barrier becomes leaky (Deen et al., 1982).

\section{Hypoalbuminaemia and proteinuria}

The liver of a normal $70 \mathrm{~kg}$ person can synthesize albumin at the rate of $8-14 \mathrm{~g} / \mathrm{d}$ (Rothschild et al., 1972), yet in nephrotic syndrome, hypoalbuminaemia occurs with considerably lower urinary protein excretion rates. Nephrotic range proteinuria is usually defined as greater than $5 \mathrm{~g} / \mathrm{d}$ and nephrotic syndrome can occur with a urinary protein excretion as low as $3.5 \mathrm{~g} / \mathrm{d}$. Although in some patients urinary protein losses may exceed the normal rate of synthesis of albumin by the liver, it is not clear why hypoalbuminaemia should occur in those patients with lesser degrees of proteinuria. There are three possible explanations: (1) albumin synthesis could be diminished; (2) non-renal losses of albumin could occur; or (3) albumin catabolism could be enhanced.

There is no evidence of decreased albumin synthesis in patients with nephrotic syndrome. Studies using radioiodinated albumin have shown that albumin synthesis in patients with nephrotic syndrome is either normal or slightly increased (Gitlin et al., 1956; Jensen et al., 1967). Non-renal losses of albumin may occur, 
probably through the gastrointestinal tract, though the evidence is conflicting. Jensen et al. (1967) and Yssing et al. (1969) in their studies found no evidence of increased gastrointestinal losses but a later study by Schultze et al. (1980) using ${ }^{51} \mathrm{Cr}$-albumin did show moderate to severe gastrointestinal protein losses in many patients with nephrotic syndrome.

The most likely explanation of the hypoalbuminaemia of nephrotic syndrome, however, is increased catabolism of albumin, probably by the kidney. Studies in both animal models (Katz et al., 1963) and in patients with nephrotic syndrome (Jensen et al., 1967) have demonstrated an increase in fractional albumin catabolism. The most likely site of this increased albumin catabolism is the kidney since there appears to be a direct relationship between renal albumin catabolism and quantitative proteinuria (Katz et al., 1963), and bilateral nephrectomy causes at least a $50 \%$ fall in the rate of plasma albumin breakdown in rats with aminonucleoside or nephrotoxic serum-induced nephrotic syndrome (Katz et al., 1964).

The site of this increased renal albumin catabolism is probably the proximal tubule. Radioiodinated albumin has been clearly demonstrated to be taken up by proximal tubule cells and perhaps then metabolized by lysozomes (Maunsbach, 1966). Proximal tubule cells have been shown to be able to metabolize a variety of plasma proteins (Waldmann et al., 1972). Micropuncture studies, however, have failed to confirm that significant albumin catabolism occurs at the proximal tubule. Studies in both aminonucleosideinduced (Oken et al., 1971, 1972; Lewy \& Pesce, 1973) and nephrotoxic serum-induced nephrotic syndrome (Landwehr et al., 1977) also gave no evidence that proximal tubular absorption plays a major role in albumin catabolism. However, Cortney et al. (1970) did find significant proximal tubular albumin absorption after injecting radioiodinated albumin into the proximal tubule.

Although the evidence is conflicting it would appear that the most likely explanation for the discrepancy between the hepatic capacity to synthesize albumin and the degree of albuminuria in many patients with nephrotic syndrome remains the increased albumin catabolism by the kidney, plus, possibly in some patients, increased gastrointestinal protein losses.

\section{Hypoalbuminaemia and oedema formation}

By Starling's law, the formation of interstitial fluid is dependent upon the balance between the hydrostatic and the oncotic pressures in the intravascular and interstitial fluid spaces, so, theoretically, oedema should occur when the plasma albumin concentration, and consequently the oncotic pressure, are low. A low plasma albumin concentration, however, is not always accompanied by oedema formation. Even patients with analbuminaemia are not oedematous and, in fact, can have an exaggerated natriuresis in response to a small saline load (Bennhold et al., 1960). Similarly, severe hypoalbuminaemia induced in animals by plasmapheresis does not produce any change in urinary sodium excretion (Vereerstraeten \& Toussaint, 1969).

Volume receptors have not been detected in the interstitial space, so control of the volume of the interstitial fluid compartment appears to be by the interplay of a number of local automatic mechanisms (Aukland \& Nicolaysen, 1981). One of the primary factors preventing oedema formation is structural resistance against volume changes making the interstitial space relatively noncompliant. Guyton (1965) found that at near normal interstitial volumes, small increases in interstitial volume cause large increases in interstitial pressure which would oppose further transudation of fluid into the interstitial space. However, once interstitial pressure reaches a critical value, as the interstitial volume increases further, the subsequent increments in interstitial pressure are much smaller. The lymphatics also play a role in preventing oedema formation. Lymph flow has been shown to increase following oedema formation in many different oedema states (Hollander et al., 1961; Zweifach, 1972) Erdmann et al. (1975) showed that during steady state elevations of pulmonary micro-vascular hydrostatic pressure, lymph flow increased while the lymph protein concentration decreased, reflecting washout of interstitial protein. The consequent decrease in interstitial oncotic pressure, by increasing the oncotic pressure gradient across the capillary wall would also help to prevent further oedema formation. One further mechanism which may protect against oedema formation is that the capillary wall appears to become less permeable to albumin in the presence of hypoalbuminaemia (Wraight, 1974; Aukland \& Nicolaysen, 1981). This would tend to prevent a further fall in plasma oncotic pressure along the capillary and therefore minimize oedema formation.

These control mechanisms preventing oedema formation have also been observed in patients with nephrotic syndrome. Increased lymphatic flow has been observed in patients with nephrotic syndrome (Hollander et al., 1961; Zweifach, 1972). Furthermore, using wick techniques, Noddeland et al. (1980) found that the interstitial oncotic pressure fell during oedema formation in patients with nephrotic syndrome, presumably because of washout of the interstitial protein by the increased lymphatic flow. From these observations, it is apparent that generalized oedema only occurs in the presence of hypoalbuminaemia when there is a stimulus for the kidney to retain sodium and water since all the local control mechanisms act to reduce the oedema. 


\section{Mechanisms of sodium retention in nephrotic syndrome}

The mechanisms causing sodium retention in nephrotic syndrome remain controversial. The classic pathophysiological explanation is that the fall in plasma albumin and, thereby, oncotic pressure leads to a transudation of fluid across the capillaries and a reduction of blood volume which then stimulates the renin-angiotensin-aldosterone system to retain sodium. Early studies on patients with nephrotic syndrome supported this idea since they demonstrated in many patients a low blood volume, high plasma renin activity, or raised urinary aldosterone (Hopper et al., 1970; Luetscher \& Johnson, 1954; Oliver \& Owings, 1967; Veyrat et al., 1964). Few of these measurements were carried out when patients were retaining sodium.

To study the mechanism of sodium retention in nephrotic syndrome, it is essential that the patients studied are accumulating sodium, i.e. sodium output is less than sodium intake with a consequent gain in weight each day. Patients who are oedematous, but are not gaining weight each day, although sodium overloaded, are in sodium balance, i.e. sodium excretion is equal to sodium intake.

Recent studies in patients with the nephrotic syndrome, who were retaining sodium, have shown that about half of the patients have a normal or high blood volume and low or normal plasma renin activity and aldosterone (Kelsch et al., 1972; Meltzer et al., 1979; Dorhout Mees et al., 1979; Brown et al., 1982a,b). We have now studied 18 patients all of whom were retaining sodium. While 10 of these 18 patients did have an elevated plasma renin activity, the other 8 patients had a low or normal plasma renin activity and a low or normal plasma aldosterone; 5 of these 8 patients had a normal or elevated blood volume. There was therefore no evidence of stimulation of the reninangiotensin-aldosterone system in these 8 patients, so some other mechanism is probably responsible for the observed sodium retention.

From these studies, it does appear that in some patients with nephrotic syndrome, stimulation of the renin-angiotensin-aldosterone system does occur as a compensatory phenomenon to a low blood volume, but it is possible that even in these patients there is some other mechanism causing the sodium retention. If the raised angiotensin II and aldosterone does indeed cause the sodium retention in these patients, there must be some explanation as to why the usual 'escape' phenomenon seen after prolonged infusions of angiotensin II (Ames et al., 1965) and aldosterone (August et al., 1958; Barger et al., 1958) into normal subjects does not occur.

Studies in rats with aminonucleoside-induced nephrotic syndrome show that oedema can develop despite bilateral adrenalectomy (Kalant et al., 1962).
More direct evidence about the role of angiotensin II and aldosterone in the sodium retention of nephrotic syndrome is obtained by blocking the renin-angiotensin-aldosterone system. Indeed, in normal subjects, it has been shown that angiotensin-converting enzyme inhibition preventing the formation of angiotensin II causes a marked natriuresis (McCaa et al., 1978; MacGregor et al., 1980). This is in marked contrast to the effect of giving the angiotensin-converting enzyme inhibitor, captopril, to patients with nephrotic syndrome (Brown et al., 1982b, 1984), when there was no increase in urinary sodium excretion and patients continued to retain sodium and gain weight. Even nephrotic patients with elevated plasma renin activity and plasma aldosterone continued to retain sodium when given captopril, despite plasma aldosterone falling to normal.

Volume expanding patients with nephrotic syndrome is another method of determining whether the sodium retention is related to the low blood volume stimulating the renin-angiotensin-aldosterone system. Following albumin infusion, there is a rise in plasma albumin and expansion of the blood volume, yet patients continue to retain sodium (Janeway et al., 1944; Luetscher, 1944; Leutscher et al., 1949) despite a fall in plasma renin activity and plasma aldosterone from high to extremely low levels (Brown et al., 1982b).

Recently, it has been found that patients with nephrotic syndrome have a natriuresis and a fall in plasma renin activity and plasma aldosterone following short term water immersion regardless of whether the plasma renin activity or plasma aldosterone was elevated before immersion (Berlyne et al., 1981; Krishna \& Danovitch, 1982). In normal subjects, water immersion also causes a natriuresis which is associated with an expansion of the central blood volume (Epstein, 1976) and a rapid fall in plasma renin activity and plasma aldosterone (Epstein \& Saruta, 1971). It is unlikely that the onset of this natriuresis is caused by the fall in aldosterone since aldosterone action has a half-life of at least $30 \mathrm{~min}$. Furthermore, pharmacological doses of mineralocorticoids do not abolish the natriuresis of water immersion in normal man (Epstein et al., 1973). Studies in normal man suggest that this natriuresis is due to expansion of central blood volume and the release of a natriuretic hormone (Epstein et al., 1978). This is probably also true in nephrotic patients, since the natriuresis induced by water immersion is directly related to the pre-immersion plasma volume (Krishna \& Danovitch, 1982).

In patients with nephrotic syndrome due to minimal change glomerulonephritis, steroid-induced remission causes a massive natriuresis up to a urinary sodium excretion of $600 \mathrm{mmol} / 24 \mathrm{~h}$ (Brown et al., 1985). Studying such patients, especially if they are known to have initial high plasma renin activity and low blood 
volume, would establish whether the switching off of the stimulus for sodium retention at the onset of natriuresis is caused by changes in the renin-angiotensin-aldosterone system. Oliver (1963) found that the onset of natriuresis occurred without any change in plasma albumin or blood volume. In a recent study of 6 patients undergoing steroid-induced remission we also found that plasma albumin and blood volume remain low even at the height of the natriuresis. During the natriuresis, there was a fall from high to normal levels in plasma renin activity and plasma aldosterone which then rose again to their previous high levels as patients came back into sodium balance; there was then no evidence of further sodium retention despite the high levels of renin and aldosterone (Brown et al., 1985). The temporary fall in plasma renin activity and plasma aldosterone is probably due to the fact that during the natriuresis, distal tubular sodium and chloride concentration rises markedly and this, through the macula densa, inhibits renin release (Davis \& Freeman, 1976). These results support the increasing evidence that, in patients with nephrotic syndrome, although the renin-angiotensin-aldosterone system can be stimulated by a low blood volume, it does not contribute towards the sodium retention.

What, then, does cause the sodium retention? It is most likely to be some intrarenal mechanism. By infusing puromycin aminonucleoside into the renal artery of one kidney while simultaneously venting the renal venous effluent, it is possible to induce heavy proteinuria from only that one kidney. Using this rat model, both Chandra et al. (1981) and Ichikawa et al. (1983) found that urinary sodium excretion was decreased in the perfused but not in the control kidney; there was no change in plasma albumin concentration.

Evidence for an intrarenal mechanism causing sodium retention in patients with nephrotic syndrome is more circumstantial. The evidence from studies of patients during steroid-induced remission does suggest that some intrarenal defect causing the sodium retention is corrected resulting in a large natriuresis. There is also indirect evidence of renal haemodynamic disturbances in patients with nephrotic syndrome

\section{References}

AMES, R.P., BARKOWSKI, A.J., SCINSKI, A.M. \& LARAGH, J.H. (1965). Prolonged infusions of angiotensin II and norepinephrine and blood pressure, electrolyte balance, aldosterone and cortisol secretion in normal man and in cirrhosis with ascites. Journal of Clinical Investigation, 44, 1171.

AUGUST, J.T., NELSON, D.H. \& THORN, G.W. (1958). Response of normal subjects to large amounts of aldosterone. Journal of Clinical Investigation, 37, 1549.

AUKLAND, K. \& NICOLAYSEN, G. (1981). Interstitial fluid since, as discussed by Searle et al. (1985) in this journal, renal failure can occur in the absence of hypotension and unexplained by pathological findings.

The actual nephron site of the increased sodium reabsorption is also not fully established. Studies of water clearance in patients with nephrotic syndrome suggest that proximal tubular sodium reabsorption is increased (Gur et al., 1976; Dorhout Mees et al., 1981) while other studies suggest that proximal reabsorption is decreased and that it is distal tubular reabsorption which is increased (Grausz et al., 1972, Bohlin \& Berg, 1984). Micropuncture studies of experimentally-induced nephrotic syndrome are equally confusing (Bernard et al., 1978; Kuroda et al., 1979), though it does appear that in the unilateral aminonucleoside perfused kidney model of Ichikawa et al. (1983), comparison of the perfused and normal kidney suggests that the site of the increased sodium reabsorption is in the late distal tubule and/or collecting duct.

If an intrarenal mechanism is the overriding cause of sodium retention in nephrotic syndrome, why is the renin-angiotensin-aldosterone system stimulated in some patients and not in others? Meltzer et al. (1979) suggested that this occurs in the presence of a low blood volume and in his series all such patients had minimal change glomerulonephritis. This correlation with the histological diagnosis is not supported by the data of Dorhout Mees et al. (1979) or by our own data (Brown et al., 1982a). It is likely that the renino angiotensin-aldosterone system is stimulated in those patients with a greater loss of albumin from the kidney resulting in more severe hypoalbuminaemia and hence low blood volume which then stimulates renin release. This theory appears to be substantiated by finding a significant inverse correlation between plasma renin activity and plasma albumin (Brown et al., 1982a). In normal man, a diminution of blood volume and stimulation of the renin system is a potent mechanism causing sodium retention by the kidney. In nephrotic syndrome, however, there appears to be an overriding mechanism, probably intrarenal, causing sodium retention independent of the renin system. The nature of this postulated intrarenal defect is as yet unknown.

volume; local regulatory mechanisms. Physiology Review 61, 556.

BARGER, A.C., BERLIN, R.D. \& TULENKO, J.F. (1958). Infusion of aldosterone, 9-fluorohydrocortisone and antidiuretic hormone into the renal artery of normal and adrenalectomized, unanaesthetized dogs: effect on electrolyte and water excretion. Endocrinology, 62, 804.

BENNET, C.M., GLASSOCK, R.J., CHANGE, R.L.C., DEEN, W.M., ROBERTSON, C.R. \& BRENNER, B.M. (1976). Permselectivity of the glomerular capillary wall: studies of 
experimental golumerulonephritis in the rat using dextran sulfate. Journal of Clinical Investigation, 57, 1287.

BENNHOLD, H., KLAUS, D. \& SCHEWLEN, P.G. (1960). Volume regulation and renal function in analbuminaemia. Lancet, ii, 1169.

BERLYENE, G.M., SUTTON, J., BROWN, C., FEINROTH, M.V., FEINROTH, M., ADLER, A.J. \& FRIEDMAN, E.A. (1981). Renal salt and water handling in water immersion in the nephrotic syndrome. Clinical Science, 61, 605.

BERNHARD, D.B., ALEXANDER, E.A., COUSER, W.G. \& LEVINSKY, N.G. (1978). Renal sodium retention during volume expansion in experimental nephrotic syndrome. Kidney International, 14, 478.

BLAU, E.B. \& HAAS, D.E. (1973). Glomerular sialic acid and proteinuria in human renal disease. Laboratory Investigation, 28, 477.

BOHLIN, A.B. \& BERG, U. (1984). Renal sodium handling in minimal change nephrotic syndrome. Archives of Disease in Childhood, 59, 825.

BOHRER, M.P., BAYLIS, C., ROBERTSON, C.R. \& BRENNER, B.M. (1977). Mechanism of the puromycin-induced defects in the transglomerular passage of water and macromolecules. Journal of Clinical Investigation, 60, 152.

BROWN, E.A., MARKANDU, N.D., ROULSTON, J.E., JONES, B.E., SQUIRES, M. \& MACGREGOR, G.A. (1982a). Is the renin-angiotensin-aldosterone system involved in the sodium retention in the nephrotic syndrome? Nephron, 32, 102.

BROWN, E.A., MARKANDU, N.D., SAGNELLA, G.A., SQUIRES, M., JONES, B.E. \& MACGREGOR, G.A. (1982b). Evidence that some mechanism other than the renin system causes sodium retention in nephrotic syndrome. Lancet, ii, 1237.

BROWN, E.A., MARKANDU, N.D., SAGNELLA, G.A., JONES, B.E. \& MACGREGOR, G.A. (1984). Lack of effect of captopril on the sodium retention of the nephrotic syndrome. Nephron, 37, 43.

BROWN, E.A., MARKANDU, N.D., SAGNELLA, G.A., JONES, B.E. \& MACGREGOR, G.A. (1985). Sodium retention in nephrotic syndrome is due to an intrarenal defect: evidence from steroid-induced remission. Nephron, 39, 290.

CHANDRA, M., HOYER, J.R.. \& LEWY, J.E. (1981). Renal function in rats with unilateral proteinuria produced by renal perfusion with aminonucleoside. Pediatric Research, $15,340$.

CHANG, R.L.S., DEEN, W.M., ROBERTSON, C.R. \& BRENNER, B.M. (1975). Permselectivity of the glomerular capillary wall: III. Restricted transport of polyanions. Kidney International, 8, 212.

CORTNEY, M.A., SAIVIN, L.L. \& WEISS, D.D. (1970). Renal tubular protein absorption in the rat. Journal of Clinical Investigation, 49, 1.

DAVIS, J.O. \& FREEMAN, R.H. (1976). Mechanisms regulating renin release. Physiology Review, 56, 1.

DEEN, W.M., MYERS, B.D. \& BRENNER, B.M. (1982). The - glomerular barrier to macromolecules: theoretical and experimental considerations. In Nephrotic Syndrome, Brenner, B.M. \& Stein, J.H. (eds). Chapter I, pp. 1-29. Churchill Livingstone: Edinburgh.

DORHOUT MEES, E.J., ROOS, J.C., BOER, P., YOE, O.H. \& SIMATUPANG, T.A. (1979). Observations on oedema formation in the nephrotic syndrome in adults with minimal lesions. American Journal of Medicine, 67, 378.
DORHOUT MEES, E.J., vd MEIRACKER, A.H., ROOS, J.C., BOER, P. \& KOOMANS, H.A. (1981). Effects of plasma volume expansion on renal salt handling and plasma renin activity in patients with nephrotic syndrome. Abstract. 8th International Congress of Nephrology, p. 286.

EPSTEIN, M. \& SARUTA, T. (1971). Effect of water immersion on renin-aldosterone and renal sodium handling in normal man. Journal of Applied Physiology, 31, 368.

EPSTEIN, M., KATSIKAS, J.L. \& DUNCAN, D.C. (1973). Role of mineral corticosteroids in the natriuresis of water immersion in normal man. Circulation Research, 32, 228.

EPSTEIN, M. (1976). Cardiovascular and renal effects of head-out water immersion in man: application of the model in the assessment of volume homeostasis. Circulation Research, 39, 619.

EPSTEIN, M., BRICKER, N.S. \& BOURGOIGNIE, J.J. (1978). Presence of a natriuretic factor in urine of normal man undergoing water immersion. Kidney International, 13, 152.

ERDMANN, A.J., VAUGHAN, T.R. \& BRIGHAM, K.L. (1975). Effect of increased vascular pressure on lung fluid balance in unanaesthetised sheep. Circulation Research, 37, 271.

GITLIN, D., JANEWAY, C.A. \& FARR, L.E. (1956). Studies on the metabolism of plasma proteins in the nephrotic syndrome, I. Albumin, $\alpha$-globulin and iron-binding globulin. Journal of Clinical Investigation, 35, 45.

GRAUSZ, H., LIEBERMAN, R. \& EARLEY, L.E. (1972). Effect of plasma albumin on sodium reabsorption in patients with nephrotic syndrome. Kidney International, 1, 47.

GUR, A., ADEFUIN, P.Y. SIEGEL, N.J. \& HAYSLETT, J.P. (1976). A study of the renal handling of water in lipoid nephrosis. Paediatric Research, 10, 197.

GUYTON, A.C. (1965). Interstitial fluid pressure: II Pressurevolume curves of interstitial space. Circulation Research, 16, 452 .

HOLLANDER, W., REILLY, P. \& BURROWS, B.A. (1961). Lymphatic flow in human subjects as indicated by the disappearance of ${ }^{131}$ I labelled albumin from the subcutaneous tissue. Journal of Clinical Investigation, 40, 222.

HOPPER, J., RYAN, P. \& LEE, J.C. (1970). Lipoid nephrosis in 31 adult patients. Medicine (Baltimore), 49, 321.

ICHIKAWA, I., RENNKE, H.G., HOYER, J.R., BADR, K.F., SCHOR, N., TROY, J.L., LECHENE, C.P. \& BRENNER, B.M. (1983). Role for intrarenal mechanism in the impaired salt excretion of experimental nephrotic syndrome. Journal of Clinical Investigation, 71, 91.

JANEWAY, C.A., GIBSON, S.T., WOODRUFF, L.M., HEYL, J.J., BAILEY, O.T. \& NEWHOUSER, L.R. (1944). Chemical, clinical and immunological studies on products of human plasma fractionation. Concentrated human serum albumin. Journal of Clinical Investigation, 23, 465.

JENSEN, H., ROSSING, N., ANDERSEN, S.B. \& JARNUM, S. (1967). Albumin metabolism in the nephrotic syndrome in adults. Clinical Science, 33, 445.

KALANT, N., DAS GUPTA, D., DESPOINTES, R. \& GIROUD, C.J.P. (1962). Mechanisms of oedema in experimental nephrosis. American Journal of Physiology, 20, 91.

KANWAR, Y.S. \& FARQUHAR, M.G. (1979). Anionic sites in the glomerular basement membrane. In vivo and in vitro localisation to the laminae rarae by cationic probes. Journal of Cell Biology, 81, 137.

KATZ, J., BONORRIS, G. \& SELLERS, A.L. (1963). Albumin metabolism in aminonucleoside nephrotic rats. Journal of 
Laboratory and Clinical Medicine, 63, 680.

KATZ, J., SELLERS, A.L. \& BONORRIS, G. (1964). Effect of nephrectomy on plasma albumin catabolism in experimental nephrosis. Journal of Laboratory and Clinical Medicine, 63, 680.

KELSCH, R.C., LIGHT, G.S. \& OLIVER, W.J. (1972). The effect of albumin infusion upon plasma norepinephrine concentration in nephrotic children. Journal of Laboratory and Clinical Medicine, 79, 516.

KRISHNA, G.G. \& DANOVITCH, G.M. (1982). Effects of water immersion on renal function in the nephrotic syndrome. Kidney International, 21, 395.

KURODA, S., AYNEDJIAN, H.S. \& BANK, N. (1979). A micropuncture study of renal sodium retention in rats: evidence for increased resistance to tubular fluid flow. Kidney International, 16, 561.

LANDWEHR, D.M., CARVALHO, J.S. \& OKEN, D.E. (1977). Micropuncture studies of the filtration and absorption of albumin by nephrotic rats. Kidney International, 11, 9.

LATTA, H., JOHNSTON, W.H. \& STANLEY, T.M. (1975). Sialoglycoproteins and filtration barriers in the glomerular capillary wall. Journal of Ultrasonic Research, 51, 354.

LEWY, J.E. \& PESCE, A. (1973). Micropuncture study of albumin transfer in aminonucleoside nephrosis in the rat. Paediatric Research, 7, 553.

LUETSCHER, J.A. (1944). The effect of a single injection of concentrated human serum albumin on circulating proteins and proteinuria in nephrosis. Journal of Clinical Investigation, 23, 365.

LUETSCHER, J.A., HALL, A.D. \& KREMER, V.L. (1949). Treatment of nephrosis with concentrated human serum albumin. I. Effects on the proteins of body fluids. Journal of Clinical Investigation, 28, 700.

LUETSCHER, J.A. \& JOHNSON, B.B. (1954). Chromatographic separation of the sodium-retaining corticoid from the urine of children with nephrosis, compared with observations on normal children. Journal of Clinical Investigation, 33, 276.

MCCAA, R.E., HALL, J.E. \& McCAA C.S. (1978). The effects of angiotensin I converting enzyme inhibitors on arterial blood pressure and urinary sodium excretion: Role of the renal renin-angiotensin and kallikrein-kinin systems. Circulation Research, 43 Suppl. I, 32.

MACGREGOR, G.A., MARKANDU, N.D., ROULSTON, J.E., JONES, J.C. \& MORTON, J.J. (1980). The renin-angiotensinaldosterone system in the maintenance of blood pressure, aldosterone secretion and sodium balance in normotensive subjects. Clinical Science, 59, $95 \mathrm{~s}$.

MAUNSBACH, A.B. (1966). Absorption of $I^{131}$ labelled homologous albumin by rat kidney proximal tubule cells. Journal of Ultrastructural Research, 15, 197.

MELTZER, J., KEIM, H., LARAGH, J., SEALEY, J., JAN, K. \& CHIEN, S. (1979). Nephrotic syndrome: vasoconstriction and hypervolemic types indicated by renin-sodium profiling. Annals of Internal Medicine, 91, 688.

MICHAEL, A.F., BLAU, E. \& VERNIER, R.L. (1970). Glomerular polyanion: Alteration in aminonucleoside nephrosis. Laboratory Investigation, 23, 649.

NODDELAND, H., MIDTBO RUSNES, S. \& FADNES, H.O. (1980). Interstitial colloid osmotic pressure in patients with hypoproteinaemia. Acta Physiologica Scandinavica, 108, 16A.

OKEN, D.E. \& FLAMENBAUM, W. (1971). Micropuncture studies of proximal tubule albumin concentrations in normal and nephrotic rats. Journal of Clinical Investigation, 50, 1498.

OKEN, D.E., COTES, S.C. \& MENDE, C.W. (1972). Micropuncture study of tubular transport of albumin in rats with aminonucleoside nephrosis. Kidney International, 1, 3.

OLIVER, W.J. (1963). Physiologic responses associated with steroid-induced diuresis in the nephrotic syndrome. Journal of Laboratory and Clinical Medicine, 62, 449.

OLIVER, W.J. \& OWINGS, C.L. (1967). Sodium excretion in the nephrotic syndrome. American Journal of Diseases in Children, 113, 352.

ROTHSCHILD, M.A., ORATZ, M. \& SCHREIBER, S.S. (1972). Albumin synthesis. New England Journal of Medicine, 286, 748.

SCHULTZE, G., AKUJA, S., FABER, U. \& MOLZAHN, M. (1980). Gastrointestinal protein loss in the nephrotic syndrome studied with ${ }^{51} \mathrm{Cr}$-albumin. Nephron, 25, 227.

SEARLE, M., COOPER, C., ELLIMAN, J., DATHAN, R. \& MACIVER, A. (1985). Reversibility of acute renal failure in elderly patients with the nephrotic syndrome. Post graduate Medical Journal, 61, 741.

VEREERSTRAETEN, P. \& TOUSSAINT, C. (1969). Effects $\alpha \overline{\bar{B}}$ plasmapheresis on renal haemodynamics and sodium ${ }^{+}$ excretion in dogs. Pflugers Archives, 306, 92.

VEYRAT, R., DE CHAMPLAIN, J., BOUCHER, R., GENEST, J. (1964). Measurement of human arterial renin activity in some physiological and pathological states. Canadian Medical Association Journal, 90, 215.

WALDMANN, T.A., STROBER, W., MOGIELRUCKI, P.R. (1972). The renal handling of low molecular weight proteins: II disorders of serum protein catabolism in patients with tubular proteinuria, the nephrotic syndrome or uraemia. Journal of Clinical Investigation, 51, 2162.

WRAIGHT, E.P. (1974). Capillary permeability to protein as a factor in the control of plasma volume. Journal of Physiology, 237, 39.

YSSING, M., JENSEN, H. \& JARNUM, S. (1969). Albumin metabolism and gastrointestinal protein loss in children with nephrotic syndrome. Acta Paediatrica Scandinavica, 58, 109.

ZWEIFACH, B.W. (1972). Capillary filtration and mechanism of oedema formation. Pflugers Archives, 336 suppl., s81. 